\title{
Two new anisophyllous species of Sabicea Aubl. (Rubiaceae) from Gabon
}

\author{
Olivier Lachenaud \& Lise Zemagho
}

\begin{abstract}
LACHENAUD, O. \& L. ZEMAGHO (2015). Two new anisophyllous species of Sabicea Aubl. (Rubiaceae) from Gabon. Candollea 70: $219-229$. In English, English and French abstracts. DOI: http://dx.doi.org/10.15553/c2015v702a7

Two new Rubiaceae species, Sabicea golgothae O. Lachenaud \& Zemagho and Sabicea mabouniensis O. Lachenaud \& Zemagho, are described and illustrated. These two species are very similar to each other, and differ from all their congeners by the combination of strong anisophylly and pedunculate inflorescences. Their position in the genus is discussed. Both species are apparently endemic to the Mabounié area in West-Central Gabon, currently under exploitation prospects for mining. They are both assessed as "Critically Endangered" according to IUCN Categories and Criteria.
\end{abstract}

\section{Résumé}

LACHENAUD, O. \& L. ZEMAGHO (2015). Deux nouvelles espèces anisophylles du genre Sabicea Aubl. (Rubiaceae) décrites du Gabon. Candollea 70: 219-229. En anglais, résumés anglais et français. DOI: http://dx.doi.org/10.15553/c2015v702a7

Deux nouvelles espèces de Rubiaceae, Sabicea golgothae O. Lachenaud \& Zemagho et Sabicea mabouniensis O. Lachenaud \& Zemagho, sont décrites et illustrées. Ces deux espèces sont très semblables entre elles, et diffèrent de tous leurs congénères par le fait quelles présentent à la fois une anisophyllie très marquée et des inflorescences pédonculées. Leur position au sein du genre est discutée. Les deux espèces paraissent endémiques de la région de Mabounié dans le centre-ouest du Gabon, qui fait l'objet d'un projet d'exploitation minière. Toutes deux sont évaluées comme «En Danger Critique d'Extinction» selon les Catégories et les Critères de l'UICN.

\section{Keywords}

RUBLACEAE - Sabicea - Gabon - Mabounié - Anisophylly - New species - Taxonomy - Conservation status

\footnotetext{
Addresses of the authors:

OL: Botanic Garden Meise, Domein van Bouchout, 1860 Meise, Belgium. E-mail: olivier.lachenaud@jardinbotaniquemeise.be

LZ: Department of Plant Systematics, University of Bayreuth, 95440 Bayreuth, Germany and Plant Systematic and Ecology Laboratory, Higher Teachers'Training College, University of Yaoundé I, P.O. Box 047, Yaoundé, Cameroon.

Submitted on June 26, 2015. Accepted on July 17, 2015.

Edited by M.W. Callmander
} 


\section{Introduction}

Gabon, a country situated on the Atlantic coast of Central Africa, is well-known for its rich flora counting many national endemics. Sosef et al. (2006) reported 4710 species of vascular plants in the country, of which 508 (c. 11\%) are only known from Gabon. These numbers are approximate since the flora of Gabon, and of Central Africa in general, is still imperfectly known. Some species previously considered endemic to Gabon have since then been discovered in neighbouring countries, such as Congo-Brazzaville (Lachenaud, 2009). On the other hand, additional Gabonese endemics are described every year (e.g. Sosef et al., 2007; BISSIENGOU \& Sosef, 2008; Janssens et al., 2010; Ntore et al., 2010; Breteler, 2011; Fischer \& Lachenaud, 2013; LachenAUD et al., 2013; Lye, 2014), often from recent collections made in previously little-known or even unexplored areas.

The Mabounié region, situated east of Lambaréné on the lower course of the Ngounié river, was one such area completely unknown to botanists until recently. Plant collections made in this area between 2011 and 2014, as part of an environmental impact assessment for a mining project, resulted in the discovery of several new species. Among these are the two remarkable species of Sabicea Aubl. (Rubiaceae, Sabiceeae), which are described here.

The genus Sabicea, in the broad sense, includes c. 145 species (Govaerts et al., 2013) which are distributed mostly in tropical Africa and South America, with a few species in Madagascar and one in Sri Lanka. They are usually small twining lianas or creepers occurring in forest edges, and are often abundant along forest tracks. The genus is characterised by axillary inflorescences, valvate corolla aestivation, soft fleshy fruits with numerous small seeds, and absence of raphides (Dessein et al., 2001; Khan et al., 2008).

The African species of Sabicea have not been revised as a whole since Wernham's (1914) worldwide monograph of the genus, although a new revision is underway by LZ. Valuable local treatments have been published for West Africa (Hepper, 1963), Gabon (Hallé, 1966) and East Africa (Verdcourt \& Bridson, 1988). The African species of Sabicea s.1. are morphologically quite diverse, and some have been placed in the segregate genera Pseudosabicea N. Hallé, Ecpoma K. Schum. and Stipularia P. Beauv. (Hallé, 1963, 1966), while other authors have included them in a more broadly circumscribed Sabicea (e.g. Hepper, 1958, 1963). The main characters used for generic segregation were the habit, and the number of ovary locules: Sabicea s.str. included only twining plants with 5-locular ovaries, Pseudosabicea was characterised by 2-locular ovaries and a sarmentose or creeping (but not twining) habit, while Ecpoma and Stipularia both comprised erect plants, with 2-locular ovaries in the case of the former, and 3- to 5-locular ovaries combined with a peculiar urn-shaped involucre, in the latter. Based on molecular evidence, KHAN et al. (2008) proposed a broad circumscription for Sabicea including all the segregate genera, a position which is followed here.

The genus Sabicea is particularly well-represented in Gabon, with c. 45 species according to our analysis. The "Flore du Gabon" (Hallé, 1966) only lists 20 species of Sabicea s.s. and 33 when the segregate genera are included, but several additions have been made in subsequent literature (Hallé, 1971; Walters et al., 2011; ZEMAGHo et al., 2014) and a number of species, most of them discovered in recent years, are currently under description. Gabon is therefore the main center of species diversity of the genus (the second richest country being Cameroon with c. 36 species) and Sabicea is among the ten most species rich genera in the Gabonese flora.

The two species described here, Sabicea golgothae O. Lachenaud \& Zemagho and S. mabouniensis O. Lachenaud \& Zemagho, appear to be morphologically closely related, and according to our current knowledge, are both endemic to the Mabounié area. They correspond well with the general characteristics of the genus, but differ from all other species described so far (WERnHAM, 1914; Hepper, 1963; Hallé, 1966, 1971; Khan, 2007; Zemagho et al., 2014) by the combination of a strong anisophylly and pedunculate inflorescences. Their morphological affinities and conservation status are discussed below.

\section{Material and methods}

The descriptions are based on the study of living material, herbarium specimens, and material preserved in spirit. The following herbaria were consulted, but did not yield additional collections of the species: BR, BRLU, LBV, MPU, P, WAG and YA.

A preliminary risk of extinction assessment was made using the IUCN Red List Categories and Criteria (IUCN, 2012). The extent of occurrence (EOO) and area of occupancy (AOO) were calculated using GeoCAT (Geospatial Conservation Assessment tool; BACHMAN et al., 2011) with a cell size of $2 \mathrm{~km}^{2}$. The number of 'locations' (as defined by IUCN, 2012) was calculated with regard to the kind of threats, such that a single location may encompass more than one adjacent subpopulation.

\section{Taxonomy}

Sabicea golgothae O. Lachenaud \& Zemagho, spec. nova (Fig. 1A-D, 2, 3).

Typus: Gabon. Moyen-Ogooué: Mabounié, 046’31”S 10³2'30"E, 2.XI.2014, Lachenaud, Bidault \& Lissambou 2116 (holo-: BRLU!; iso-: BR!, G!, LBV!, MO!, P!, WAG!). 

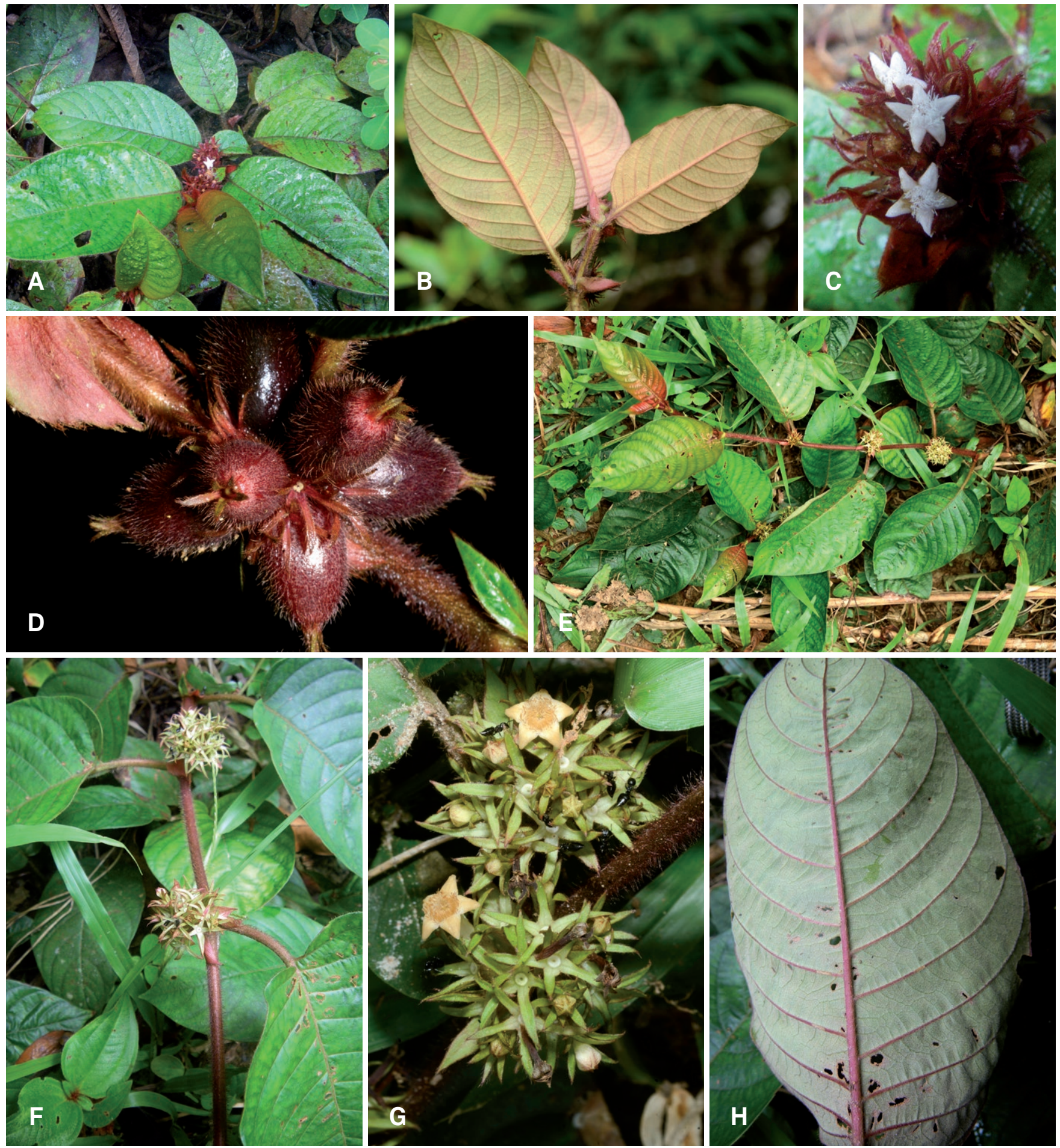

Fig. 1. - Sabicea golgothae O. Lachenaud \& Zemagho. A. Habit; B. Underside of leaves; C. Inflorescence; D. Fruits. Sabicea mabouniensis O. Lachenaud \& Zemagho. E. Habit; F. Detail of stem with inflorescences; G. Inflorescences; H. Underside of leaf. [A-D: Lachenaud et al. 2116; E-H: Lachenaud et al. 1446]

[Photos: A, C, F, H: O. Lachenaud; B, D, E, G: E. Bidault] 


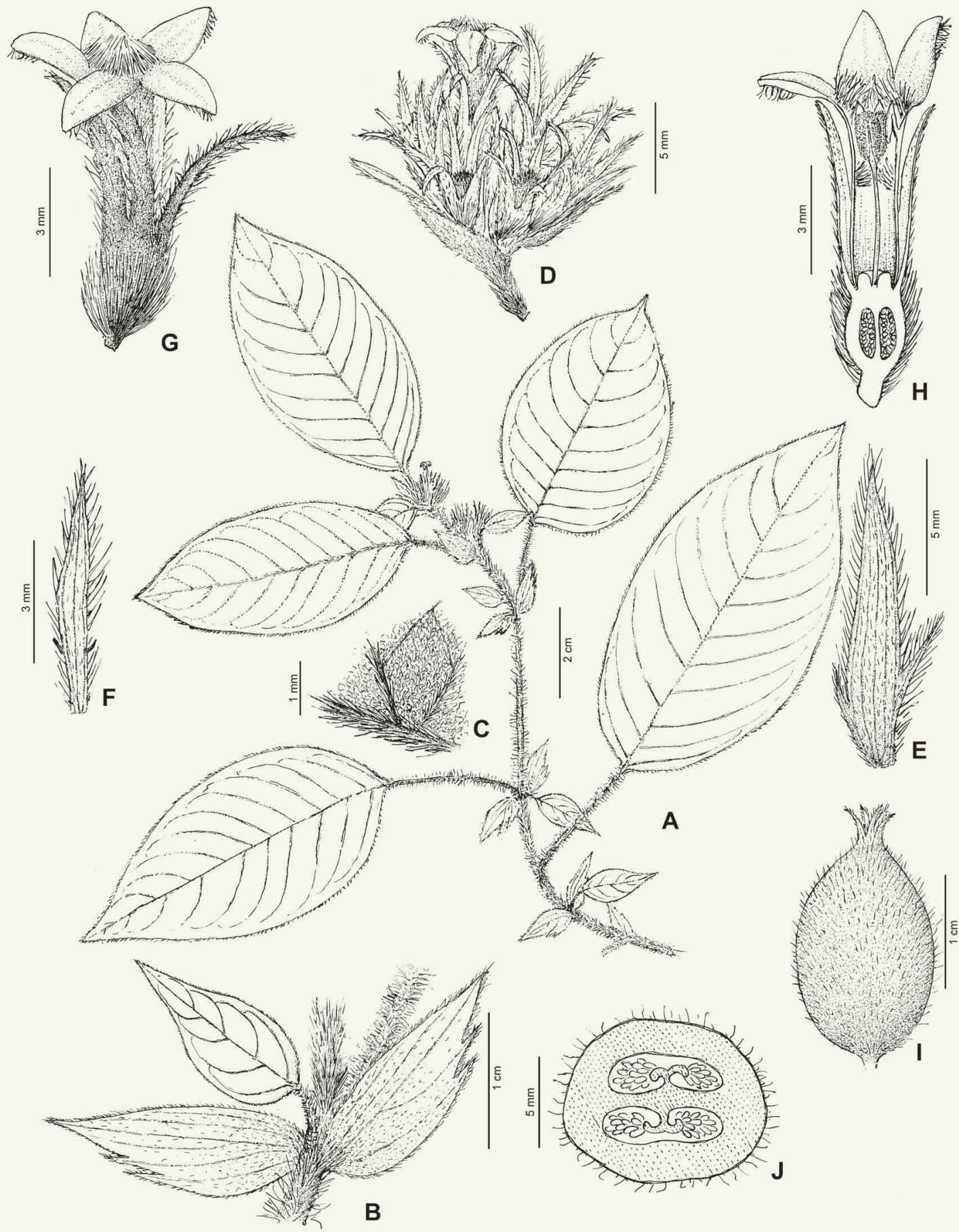

Fig. 2. - Sabicea golgothae O. Lachenaud \& Zemagho. A. Habit; B. Node with stipules and reduced leaf; C. Detail of lower leaf surface; D. Inflorescence; E-F. Bracts; G. Flower; H. Longitudinal section of flower; I. Mature fruit; J. Cross-section of fruit. [Lachenaud et al. 2116, BRLU] [Drawing: Antonio Fernandez] 
Habitu reptante, foliis valde anisophyllis, ovarioque biloculare Sabicea mabouniensi O. Lachenaud \& Zemagho, S. medusula K. Schum. ex Wernham, S. mildbraedii Wernham et S. sthenula (N. Hallé) Razafim. et al. similis est. A S. mabouniensi differt foliis basi acutis vel obtusis (nec cordatis) et valde discoloribus indumento subtus lamina obscurante, pedunculis brevioribus (0.2-0.5 nec $0.8-2 \mathrm{~cm})$, calyce rubro (nec viride), corollaque omnino alba fauce longiore barbata; ab alteris speciebus inflorescentiis breviter pedunculatis (nec sessilibus), calyce rubro, fructibusque maioribus distinguitur.

Low creeping herb, $5-15 \mathrm{~cm}$ high, with stems rooting at base; stems villous, with indumentum consisting of c. $2 \mathrm{~mm}$ long, pinkish, patent hairs, intermingled with much shorter uncinate hairs. Leaves opposite, highly unequal especially on upper nodes, often appearing alternate at first sight; reduced leaf with petiole $0-1 \mathrm{~cm}$ and lamina lanceolate to elliptic, $1.2-6.3 \times 0.3-2.9 \mathrm{~cm}$; normal leaf with petiole $1.2-3.2(-5.5) \mathrm{cm}$ long, with similar indumentum to the twigs, and lamina (5.8-)8-13.8 $\times(2.2-) 3.7-6.5 \mathrm{~cm}$, elliptic, acute to obtuse and often asymmetrical at base, acuminate at apex, papery and strongly discolorous; upper side green, with appressed stiff hairs very sparse on the lamina and denser on the nerves, where they are intermingled with shorter crisped hairs; lower side pinkish-buff, with dense persistent felt of woolly hairs (becoming sparser but still visible on old leaves), intermingled with long stiff appressed hairs on the nerves and on the margin; nerves slightly bullate above, pinkish beneath, the laterals 9-12, ascending and almost reaching the margin; tertiary veins densely reticulate and contrasting below. Stipules wine red, 2 per node, interpetiolar, erect to patent,
$12-23 \times 3.5-10.5 \mathrm{~mm}$, broadly ovate and slightly falcate, acute, entire or with 1-2 short lateral teeth, slightly veined, sparsely hairy outside with + /- appressed hairs $0.3-1 \mathrm{~mm}$ long, glabrous inside. Inflorescences axillary, solitary at each node and borne in the axil of the reduced leaf, densely glomerulate to very shortly cymose, 1.3-1.7 cm long; peduncle very short and usually hidden by the stipules, $0.2-0.5 \mathrm{~cm}$ long, with same indumentum as the stems; flowering part 1.2-1.4 $\times 1.7-2.3 \mathrm{~cm}$; ramifications not or hardly distinct, $<0.1 \mathrm{~cm}$. Bracts wine red, numerous, decreasing in size from the base to the apex of the inflorescence, not clearly forming an involucre, entire or shortly dentate, sparsely appressed-hairy outside, glabrous or with very sparse short hairs near the apex inside; lower pair of bracts broadly ovate, shortly connate at base for c. $1 \mathrm{~mm}$ and acute at apex, 11-11.5 × 5-7 mm; upper bracts lanceolate, free, acute, $6-11 \times 0.5-2.5 \mathrm{~mm}$, resembling the calyx lobes. Flowers (4-)5-merous; pedicels very short, $<1 \mathrm{~mm}$ long, densely hairy. Calyx wine red, with short tube c. $1 \mathrm{~mm}$; lobes acute, narrowly lanceolate, erect to oblique at anthesis and +/- bending outwards at apex, 5-6 × 0.6-1 mm, sparsely hairy outside with hairs 0.5-1.5 mm long, glabrous inside except short sparse hairs near their apex, alternating with short colleters at their base. Corolla pale buff in bud, pure white at anthesis and later fading to brown; tube narrow and almost cylindrical, $6 \times 1.5 \mathrm{~mm}$; lobes triangular, patent, $2 \mathrm{~mm}$ long; outside of corolla with short, c. $0.5 \mathrm{~mm}$ long stiff hairs on lobes and upper 1/4th of tube, otherwise glabrous; inside of corolla with a dense beard of (0.7-)1-1.2 mm long moniliform hairs in throat and upper part of tube, and a separate ring of shorter hairs inside the tube just above mid-height. Stamens included, inserted c. $1.5 \mathrm{~mm}$ below throat of corolla tube; anthers subsessile, c. $1 \times 0.3 \mathrm{~mm}$,

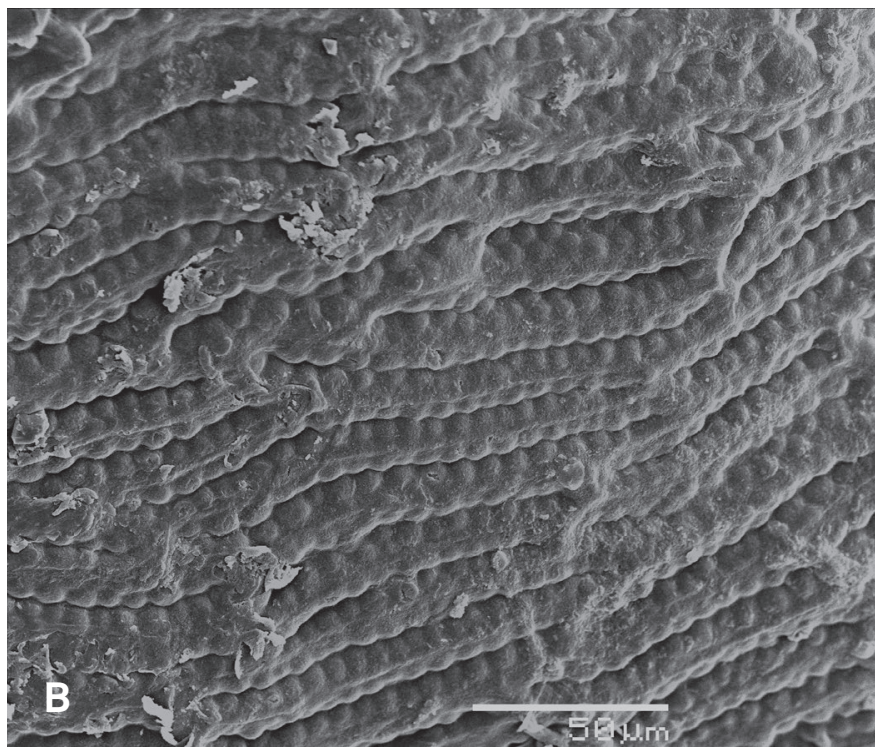

Fig. 3. - Seed of Sabicea golgothae O. Lachenaud \& Zemagho, viewed in electron microscopy. A. Entire seed; B. Detail of seed surface. [Photos: Iris van der Beeten] 
shortly apiculate. Ovary c. $2 \mathrm{~mm}$ long, densely covered with long appressed stiff hairs, 2-locular in cross-section. Disk shortly cylindrical, c. $0.5 \mathrm{~mm}$, glabrous. Style bifid, included, about equalling the anthers, glabrous, $5.5 \mathrm{~mm}$ long including the $1.5 \mathrm{~mm}$ long stigmas, these dorsally compressed and rounded at apex. Fruits dark purple outside, with purple flesh, ovoid, with persistent calyx, 12-17 × 8-11 $\mathrm{mm}$ in life, villous with patent hairs 1-2 $\mathrm{mm}$ long, very shortly pedicellate (pedicel c. $1 \mathrm{~mm}$ long). Seeds numerous, dark brown, polygonal, c. $1 \times 0.5 \mathrm{~mm}$, the surface with dense parallel striations.

Etymology. - The species is named after Golgotha Hill in the Mabounié region, where it was first discovered, and in the vicinity of which all known subpopulations occur.

Distribution and ecology. - Sabicea golgothae is apparently endemic to the Mabounié region in West-Central Gabon (Fig. 4), where it is known from three very close sites. The new species grows in half-shaded forest edges along tracks, where it locally forms dense populations.

Conservation status. - The EOO of S. golgothae is estimated as $0.608 \mathrm{~km}^{2}$ and the $\mathrm{AOO}$ as $12 \mathrm{~km}^{2}$, respectively within the thresholds for "Critically Endangered" and "Endangered" under Criteria B1 and B2. The species is known from three subpopulations (in addition to the two subpopulations from which specimens were taken, a third was observed at $0^{\circ} 46^{\prime} 09^{\prime \prime} \mathrm{S}$ $10^{\circ} 32^{\prime} 07^{\prime \prime} \mathrm{E}$ ) which represent a single location in the sense of IUCN, and all three occur in the mining concession. One of these subpopulations at least is under immediate threat in the mining project. A decline in the $\mathrm{EOO}, \mathrm{AOO}$, extent of habitat and quality, number of subpopulations and number of individuals can therefore be predicted. Sabicea golgothae should thus be assigned a preliminary status of "Critically Endangered" [CR B1ab(i,ii,iii,iv,v)].

Notes. - Sabicea golgothae is very close to S. mabouniensis described below. Both species also resemble $S$. medusula K. Schum. ex Wernham, S. mildbraedii Wernham, and S. sthenula (N. Hallé) Razafim. et al. All these species have in common a low creeping habit, strong anisophylly (in $S$. sthenula and some rare variants of $S$. mildbraedii, the anisophylly is even extreme, with a single leaf per node) and a 2-locular ovary. The major differences between them are summarised in Table 1.

Sabicea medusula, S. mildbraedii and S. sthenula all differ from $S$. golgothae in having truly sessile inflorescences, and a green to whitish calyx. In $S$. golgothae the peduncle, although short, is always present, and the calyx is wine red; the fruits are also conspicuously larger than in the three other species.

From S. mabouniensis, S. golgothae can be distinguished by the acute to obtuse (not cordate) leaf bases, strongly discolorous leaves (with the indumentum completely obscuring the under surface, except on old leaves), more condensed inflorescences with shorter peduncles, the deep wine red colour of its bracts and calyces, and the entirely white corollas with longer hairs in the throat. These differences are slight, but appear to be constant in the subpopulations we have seen. Since the two taxa occur in the same area, only a few kilometers away from each other, and without apparent habitat discontinuity or barriers to dispersal, it seems appropriate to treat them as separate species rather than subspecies. The apparent difference in the internal indumentum of the corolla tube between $S$. golgothae (two separate rings of hairs) and S. mabouniensis (a single continuous ring) may not be significant, since we have found other Sabicea species (e.g. $S$. mildbraedii) to be variable in this respect.

The flowers of $S$. golgothae, with their anthers and style at same level, appear to be isostylous. This would be exceptional in a genus where distyly is otherwise the rule. However, since only the type collection bears open flowers, more material would be needed to confirm this character.

Paratypus. - Gabon. Moyen-Ogooué: Mabounié, Golgotha, $0^{\circ} 45$ '55”S 10³2'49”E, 31.X.2014, Lachenaud, Bidault E Lissambou 2106 (BR, BRLU, $\mathrm{LBV}, \mathrm{MO})$.

Sabicea mabouniensis O. Lachenaud \& Zemagho, spec. nova (Fig. 1E-H, 5).

Typus: Gabon. Moyen-Ogooué: Mabounié, piste du nord-est, 043'00"S 10³5'53”E, 17.XI.2013, Lachenaud, Stévart, Ikabanga, Issembé, Boupoya E Kaparidi 1446 (holo-: BR!; iso-: BRLU!, LBV!, MO!, P!, WAG!).

Habitu reptante, foliis valde anisophyllis, ovarioque biloculare Sabicea golgothae O. Lachenaud EO Zemagho, S. medusula $K$. Schum. ex Wernham, S. mildbraedii Wernham et S. sthenula (N. Hallé) Razafim. et al. similis est; sed a primo differt foliis basi cordatis indumento subtus laxiore, pedunculis longioribus (0.8-2 nec 0.2-0.5 cm), calyce viride (nec rubro), corolla lobis intus ochraceo-luteis et fauce breviore barbata; ab alteris speciebus inflorescentiis pedunculatis, foliis indumento subtus laxiore et lamina non obscurante, corollaeque lobis intus ochraceo-luteis (nec albis) conspicue distinguitur.

Low creeping herb, with stems rooting at base; stems villous with indumentum consisting of $1.5-2 \mathrm{~mm}$ long, pinkish, patent hairs, intermingled with much shorter uncinate hairs. Leaves opposite, strongly unequal especially on upper nodes, often appearing alternate at first sight; reduced leaf with petiole $0-1.3 \mathrm{~cm}$ and lamina lanceolate to elliptic, $1.1-3.6 \times 0.3-2.6 \mathrm{~cm}$; normal leaf with petiole 2-4 cm long, with similar indumentum to the twigs, and lamina 7-13.2 $\times 4.2-7.3 \mathrm{~cm}$, elliptic, subcordate and asymmetrical at base, acuminate at apex, papery and slightly 




Fig. 4. - Distribution of Sabicea golgothae O. Lachenaud \& Zemagho (white square) and S. mabouniensis O. Lachenaud \& Zemagho (circle).

discolorous; upper side green, with appressed stiff hairs very sparse on the lamina and denser on the nerves, where they are intermingled with shorter crisped hairs; lower side pale green, with short and rather sparse pinkish-white woolly hairs, intermingled with longer hairs on the nerves; nerves slightly bullate above, pinkish beneath, the laterals $9-12$, ascending and almost reaching the margin; tertiary veins densely reticulate and slightly contrasting below. Stipules pinkish-green, 2 per node, interpetiolar, erect, A12-18 × 6-9 mm, broadly ovate and slightly falcate, acute, entire or shortly bidentate, faintly veined, sparsely hairy outside with appressed hairs c. $1 \mathrm{~mm}$ long, glabrous inside. Inflorescences axillary, usually in opposite pairs but sometimes only one developing per node, in dense contracted cymes (often appearing falsely umbellate), 1.8-4 cm long; peduncle $0.8-2 \mathrm{~cm}$ long, with similar indumentum to the twigs; flowering part 1-2 × 1.4-2.7 cm; ramifications short, $<0.4(-1) \mathrm{cm}$. Bracts pale green, numerous, decreasing in size from the base to the apex of the inflorescence, not clearly forming an involucre, free or shortly connate at base for c. $1.5 \mathrm{~mm}$, entire, rather densely appressed-hairy outside and sparsely so inside; lower bracts broadly ovate, acute, 10-13 × 3-6 mm; upper bracts narrowly lanceolate, c. $8 \times 1.2 \mathrm{~mm}$, resembling the calyx lobes. Flowers 5-merous, pedicels 1-2 mm long, densely hairy. Calyx pale green (the apex of lobes often pinkish), with tube very short, c. $0.5 \mathrm{~mm}$; lobes acute, narrowly lanceolate, +/- patent at anthesis, 5-6 $\times 0.6 \mathrm{~mm}$, densely hairy outside and sparsely so inside, alternating with short colleters at their base. Corolla with white, narrow and almost cylindrical tube, $6 \times 1-1.5 \mathrm{~mm}$; lobes pale ochre-yellow inside, triangular, patent, 1.3-1.7 mm long; outside of corolla with short, c. $0.5 \mathrm{~mm}$ long appressed hairs on lobes and upper $1 / 5$ th of tube, otherwise glabrous; inside of corolla sparsely hairy in upper half of tube and more densely so around the throat, with rather short moniliform hairs c. $0.5 \mathrm{~mm}$ long. Stamens included with apex almost reaching throat; anthers sessile, $1.3 \times 0.5 \mathrm{~mm}$, shortly apiculate. Ovary c. $2 \mathrm{~mm}$ long, densely appressed-hairy, 2-locular. Disk shortly cylindrical, c. $0.3 \mathrm{~mm}$, glabrous. Style bifid, included, reaching about the mid-height of anthers, glabrous, $5 \mathrm{~mm}$ long including the $1.5 \mathrm{~mm}$ long stigmas, these dorsally compressed and rounded at apex. Fruits unknown.

Distribution and ecology. - Sabicea mabouniensis is known from a single site in the Mabounié area, in West-Central Gabon (Fig. 4). It is apparently a very rare species: although the area has been relatively well-prospected in recent years, no other sites were found. The species grows on a sunny forest edge along a track, a common habitat for species of the genus. It occurs there alongside another new species of Sabicea (Lachenaud et al. 1447); the latter is not strictly endemic to the region, and will be described elsewhere.

Conservation status. - The new species is known from a single subpopulation, representing a single location, and occurs in a mining concession. The $\mathrm{AOO}$ of $S$. mabouniensis is estimated at $4 \mathrm{~km}^{2}$, within the threshold for Critically Endangered status under Criterion B2 (the EOO is not calculable). It is thus extremely susceptible to any threat, the most important of which is deforestation for mining. Although the area where it occurs is not to be immediately affected by the mining project, we anticipate that this pressure will increase in the future. A decline in the AOO, extent and quality of habitat, number of subpopulations and number of individuals can therefore be expected, and the species should thus be assigned a preliminary status of "Critically Endangered" [CR B2ab(ii,iii,iv,v)].

Notes. - Sabicea mabouniensis is morphologically very close to $S$. golgothae, also described in this article (see under that species for more details). It also superficially resembles other low anisophyllous species ( $S$. medusula, S. mildbraedii and S. sthenula) but is quite easily separated by the pedunculate inflorescences, the weakly discolorous leaves with hairs not obscuring the under surface (vs. strongly discolorous with a dense felt of woolly hairs obscuring the under surface), and the corolla with short hairs in the throat and lobes ochre-yellow inside (vs. corolla long-bearded in the throat and with the lobes entirely white) (Table 1 ).

Only short-styled flowers have been observed in S. mabouniensis. Due to the rarity of the material, it is not possible to determine whether the species is heterostylous, as usual in the genus. 


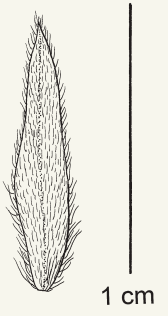

D
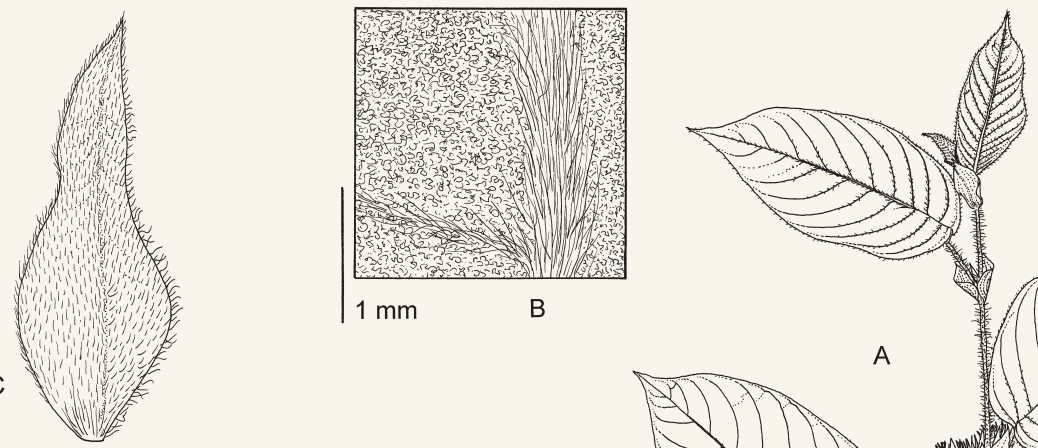

A

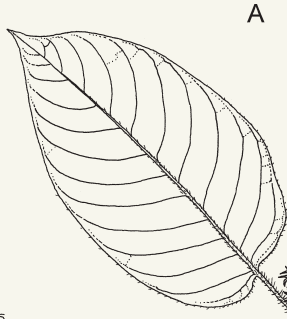

A

Hans de Vries
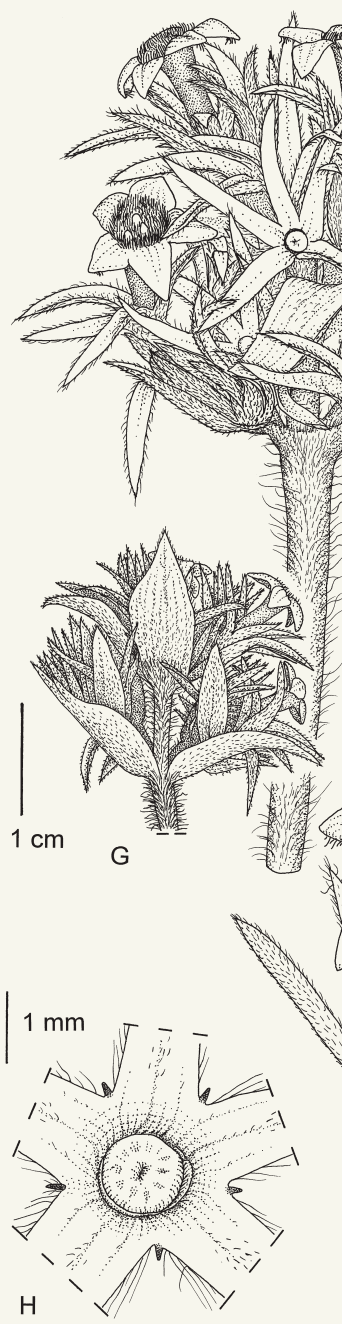

$1 \mathrm{~cm}$



$E$



美
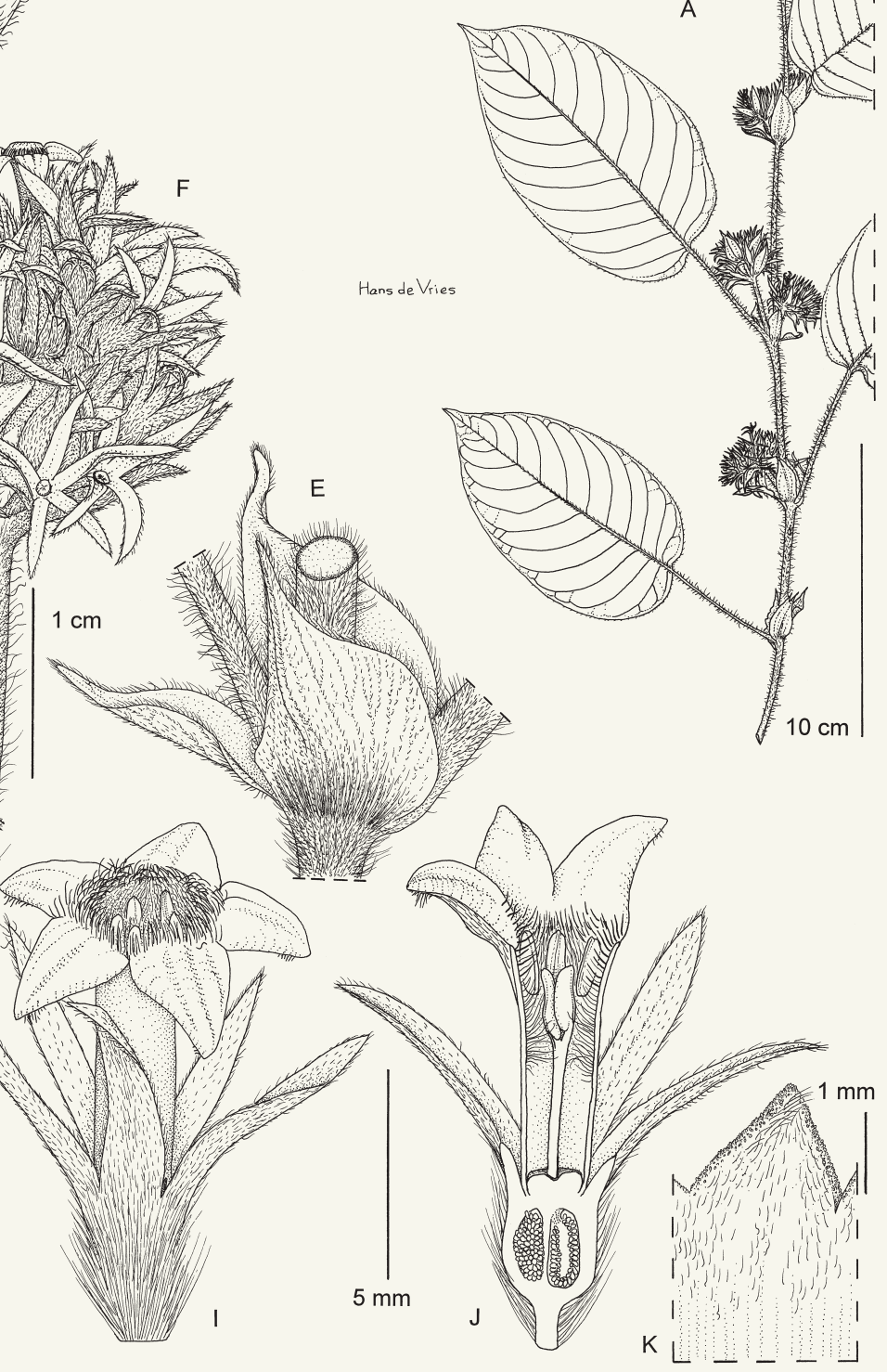

$K_{L}$

Fig. 5. - Sabicea mabouniensis O. Lachenaud \& Zemagho. A. Habit; B. Detail of lower leaf surface; C-D. Bracts;

E. Node with two stipules, one reduced leaf, one petiole and the base of a peduncle; F-G. Different views of inflorescence; H. Disk and base of calyx, seen from above; I. Flower; J. Longitudinal section of flower; K. Corolla lobe, seen from outside. [Lachenaud et al. 1446, BR \& BRLU] [Drawing: Hans de Vries] 


\section{Discussion}

\section{Position of the nerw species in the genus, and evolution of anisophylly in Sabicea}

The discovery of these two species is particularly interesting, because they are apparently not closely related to other anisophyllous Sabicea. Within Sabicea, anisophylly was previously recorded in two different groups: (1) A pair of closely related Malagasy species, S. acuminata Benth. and $S$. diversifolia Pers. - these are sarmentose shrubs with 5-locular ovaries, multifid stipules and sessile inflorescences, thus quite different from the two new species described here. (2) Another group of Central African species (hereafter referred to as the S. mildbraedii group) include $S$. aurifodinae (N. Hallé) Razafim. et al., S. batesii Wernham, S. medusula, S. mildbraedii, S. sthenula, and several undescribed related species. The habit in this group varies from sarmentose (S. aurifodinae, S. batesii) to creeping (S. medusula, S. mildbraedii, S. sthenula), and the stipules from entire to multifid. The ovary is always 2-locular and the inflorescences are sessile. The creeping species of this group are thus very similar to $S$. golgothae and $S$. mabouniensis, although these two have the inflorescences pedunculate (very shortly so in $S$. golgothae).
Species of the latter group were previously included in Pseudosabicea due to their 2-locular ovaries, and our two novelties would also have belonged to that genus in the classification of Hallé $(1963,1966)$. However, molecular studies (KHAN et al., 2008) showed Pseudosabicea to be a polyphyletic assemblage of two distinct clades. The first clade forms one of the basal lineages in Sabicea s.l. and includes the anisophyllous species of the S. mildbraedii group, while the second clade is deeply nested in Sabicea and includes species with the leaves in equal pairs, namely S. nobilis Good (the type species of Pseudosabicea), S. floribunda K. Schum., S. proselyta (N. Hallé) Razafim. et al., S. segregata Hiern, and also, based on morphology, S. sanguinosa (N. Hallé) Razafim. et al.

Molecular studies based on ITS, petD, rps16 and $\operatorname{trnT} T-F$ sequences (ZEMAGHO et al., in press) showed, surprisingly, that $S$. mabouniensis is not closely related to the $S$. mildbraedii group, but rather placed it as sister to the $S$. nobilis clade with moderate support. This is an unexpected result, since although species of the latter group have 2-locular ovaries and usually pedunculate inflorescences like $S$. mabouniensis, they are otherwise quite different in their sarmentose habit and leaves arranged in equal pairs. Unfortunately, due to its recent discovery $S$. golgothae could not be included in this molecular study.

Table 1. - Differences between Sabicea golgothae O. Lachenaud \& Zemagho, S. mabouniensis O. Lachenaud \& Zemagho and other low creeping anisophyllous species. The diagnostic characters are noted in bold.

\begin{tabular}{|c|c|c|c|c|c|}
\hline Characters & S. golgothae & S. mabouniensis & S. medusula & S. mildbraedii & S. sthenula \\
\hline Phyllotaxy & $\begin{array}{l}\text { nodes with } 2 \text { unequal } \\
\text { leaves and } 2 \text { stipules }\end{array}$ & $\begin{array}{l}\text { nodes with } 2 \text { unequal } \\
\text { leaves and } 2 \text { stipules }\end{array}$ & $\begin{array}{l}\text { nodes with } 2 \text { unequal } \\
\text { leaves and } 2 \text { stipules }\end{array}$ & $\begin{array}{l}\text { nodes with } 2 \text { unequal } \\
\text { leaves and } 2 \text { stipules } \\
\text { (rarely a single leaf } \\
\text { opposed to a stipule) }\end{array}$ & $\begin{array}{l}\text { nodes usually with } \\
1 \text { leaf and } 1 \text { stipule } \\
\text { (rarely } 2 \text { unequal } \\
\text { leaves and } 2 \text { stipules) }\end{array}$ \\
\hline Stipule shape & $\begin{array}{l}\text { entire or with 1-2 short } \\
\text { lateral teeth }\end{array}$ & $\begin{array}{l}\text { entire or shortly } \\
\text { bidentate }\end{array}$ & $\begin{array}{l}\text { entire or shortly } \\
\text { bidentate }\end{array}$ & $\begin{array}{l}\text { multifid with } 2-7 \text { lobes } \\
\text { (very rarely entire) }\end{array}$ & $\begin{array}{l}\text { multifid with 5-14 } \\
\text { lobes }\end{array}$ \\
\hline Leaf base & acute to obtuse & subcordate & obtuse to subcordate & acute to subcordate & cordate to obtuse \\
\hline Leaf underside & $\begin{array}{l}\text { strongly discolorous, } \\
\text { with dense felt of buff } \\
\text { hairs obscuring the } \\
\text { lower surface }\end{array}$ & $\begin{array}{l}\text { weakly discolorous, } \\
\text { hairs sparse on } \\
\text { adult leaves and not } \\
\text { obscuring the lower } \\
\text { surface }\end{array}$ & $\begin{array}{l}\text { strongly discolorous, } \\
\text { with dense felt of buff/ } \\
\text { whitish hairs obscuring } \\
\text { the lower surface }\end{array}$ & $\begin{array}{l}\text { strongly discolorous, } \\
\text { with dense felt of buff/ } \\
\text { whitish hairs obscuring } \\
\text { the lower surface }\end{array}$ & $\begin{array}{l}\text { strongly discolorous, } \\
\text { with dense felt of buff/ } \\
\text { whitish hairs obscuring } \\
\text { the lower surface }\end{array}$ \\
\hline Inflorescence & $\begin{array}{l}\text { shortly pedunculate } \\
\text { (peduncle } 0.2-0.5 \mathrm{~cm} \text { ), } \\
\text { not or hardly branched }\end{array}$ & $\begin{array}{l}\text { rather long } \\
\text { pedunculate (peduncle } \\
0.8-2 \mathrm{~cm} \text { ), usually } \\
\text { branched }\end{array}$ & sessile, unbranched & sessile, unbranched & sessile, unbranched \\
\hline Colour of calyx & wine red on both sides & $\begin{array}{l}\text { pale green on both } \\
\text { sides (often tinged } \\
\text { pinkish at apex) }\end{array}$ & $\begin{array}{l}\text { green, or sometimes } \\
\text { whitish outside }\end{array}$ & $\begin{array}{l}\text { whitish outside and } \\
\text { green inside }\end{array}$ & $\begin{array}{l}\text { pale green on both } \\
\text { sides }\end{array}$ \\
\hline Calyx lobes & 5-6 mm, lanceolate & 5-6 mm, lanceolate & $\begin{array}{l}\text { 3-5.5 mm, linear } \\
\text { to very narrowly } \\
\text { spathulate }\end{array}$ & $\begin{array}{l}\text { 1-3.5 mm, broadly } \\
\text { elliptic to lanceolate }\end{array}$ & 4-6 mm, lanceolate \\
\hline Colour of corolla & tube and lobes white & $\begin{array}{l}\text { tube white, lobes } \\
\text { ochre-yellow inside }\end{array}$ & tube pink, lobes white & tube and lobes white & tube pink, lobes white \\
\hline Corolla tube length & $6 \mathrm{~mm}$ & $6 \mathrm{~mm}$ & $5-6 \mathrm{~mm}$ & $3.5-4.5 \mathrm{~mm}$ & 7-7.5 mm \\
\hline Hairs in corolla throat & long: (0.7-)1-1.2 mm & short: c. $0.5 \mathrm{~mm}$ & long: c. $0.8 \mathrm{~mm}$ & long: c. $1 \mathrm{~mm}$ & long: c.1 mm \\
\hline Fruits & $\begin{array}{l}\text { dark purple, } 12-17 \times \\
8-11 \mathrm{~mm} \text { in vivo }\end{array}$ & not known & $\begin{array}{l}\text { red or whitish, c. } 10 \times \\
9 \mathrm{~mm} \text { in vivo }\end{array}$ & $\begin{array}{l}\text { green to red, c. } 9 \times \\
7 \mathrm{~mm} \text { in vivo }\end{array}$ & $\begin{array}{l}\text { green, } 5-9 \times 3.5-6 \mathrm{~mm} \\
\text { when dry }\end{array}$ \\
\hline
\end{tabular}


It appears, therefore, that anisophylly and the number of ovary locules are both homoplasic characters within Sabicea s.1. This supports an enlarged circumscription of Sabicea as proposed by Hepper $(1958,1963)$ and Khan et al. (2008).

\section{Endemism in West-Central Gabon}

Both S. mabouniensis and S. golgothae are apparently endemic to the Mabounié region in West-Central Gabon. They have never been found elsewhere, despite being easy to collect and to identify; and while it is possible that additional sites will be found in the future, both species must be very rare.

Their distribution is not easy to understand in terms of current chorological concepts, since the region where they occur lies at the border of the Coastal and Central areas recognised by CABALLÉ (1978) in his classification of Gabonese forests. However, analyses of available vegetation inventories (STÉVART, unpubl. data) suggest there may be an overlooked center of endemism in West-Central Gabon, an area roughly delimited by Ndjolé (NE), Lambaréné (NW), La Lopé (E) and Rabi (SW). Examples of species endemic to this area and relatively widespread within it are Craterispermum sp. nov. (Rubiaceae, species under description by H. Taedoumg $\&$ P. De Block), Diospyros rabiensis Breteler (Ebenaceae), Synsepalum fleuryanum A. Chev. (Sapotaceae) and Whitfieldia letestui Benoist (Acanthaceae). This area also includes a number of endemics with narrower ranges, to which Sabicea golgothae and $S$. mabouniensis presumably belong. Further studies on the distribution patterns of Gabonese endemic plants are ongoing, and should give us a better understanding of the subject.

\section{Acknowledgements}

We thank the the IPHAMETRA (Institut de Pharmacopée et de Médecine Traditionnelle) and its director, Dr Henri Paul Bourobou Bourobou, for permission to conduct research in Gabon. The two species described here were collected during the Environmental Impact Study of the Mabounié project in Gabon; the staff of the Maboumine company (Eramet) are acknowledged for their help and assistance in the field. The first author also wishes to thank Eric Akouangou, Ehoarn Bidault, Archange Boupoya, Davy Ikabanga, Yves Issembé, John Kaparidi, Brandet Lissambou, Jean-Yves Serein and Tariq Stévart for their help during field work. Lise Zemagho holds a $\mathrm{PhD}$ research grant from the Deutscher Akademischer Austausch Dienst (DAAD) for the revision of Sabicea s.l. from Continental Africa. We are grateful to Hans de Vries and Antonio Fernandez for their excellent drawings, Ehoarn Bidault for his field photographs of both species, Iris van der Beeten for her photographs of the seeds in electron microscopy, and Tariq Stévart and George Schatz for their help in the conservation status assessments. Carel Jongkind, Martin Callmander and Pete Phillipson made useful comments which helped improve the manuscript.

\section{References}

Bachman, S., J. Moat, A. W. Hill, J. de la Torre \& B. Scott (2011). Supporting Red List Threat assessments with GeoCAT: geospatial conservation assessment tool. Zookeys 150: 117-126.

Bissiengou, P. \& M. S. M. Sosef (2008). Novitates Gabonenses 69. A new endemic species of and new combination in Campylospermum (Ochnaceae). Blumea 53: 627-631.

Breteler, F. J. (2011). Novitates Gabonenses 78. Deux espèces nouvelles du Gabon dans les Bridelieae (Phyllanthaceae, autrefois Euphorbiaceae) avec clés des espèces gabonaises des genres Bridelia et Cleistanthus. Adansonia ser. 3, 33: 233-242.

Caballé, G. (1978). Essai sur la géographie forestière du Gabon. Adansonia ser. 2, 17: 425-440.

Dessein, S., L. Andersson, E. Robbrecht \& E. Smets (2001). Hekistocarpa (Rubiaceae): A member of an emended tribe Virectarieae. Pl. Syst. Evol. 229: 59-78.

Fischer, E. \& O. Lachenaud (2013). A new species of Torenia (Linderniaceae) from Gabon, remarks on Torenia mannii Skan, and a key to the African and Madagascan Torenia species. Phytotaxa 125: 40-46.

Govaerts, R., M. Ruhsam, L. Andersson, E. Robbrecht, D. Bridson, A. Davis, I. Schanzer \& B. Sonké (2013). World Checklist of Rubiaceae. The Board of Trustees of the Royal Botanic Gardens, Kew [http://www.kew.org/wcsp].

Hallé, N. (1963). Délimitation des genres Sabicea Aubl. et Ecpoma K. Schum. en regard d'un genre nouveau: Pseudosabicea (Mussaendeae-Rubiaceae). Adansonia ser. 2, 3: 168-177.

Hallé, N. (1966). Rubiacées (1re partie). In: Aubréville, A. (ed.), Fl. Gabon 12. Muséum national d'Histoire naturelle, Paris.

Hallé, N. (1971). Rubiaceae Gabonaises nouvelles du genre Pseudosabicea. Adansonia ser. 2, 11: 313-317.

Hepper, F. N. (1958). Sabicea Aubl. and Stipularia P. Beauv. (Rubiaceae-Mussaendeae) in Tropical Africa. Kew Bull. 13: 289-294.

Hepper, F. N. (1963). Sabicea. In: Hepper, F. N. (ed.), Fl. W. Trop. Africa ed. 2, 2: 169-174.

IUCN (2012). IUCN Red List Categories and Criteria: Version 3.1. $2^{\text {nd }}$ ed. IUCN Species Survival Commission, Gland \& Cambridge.

Janssens, S. B., E. Fischer \& T. Stévart (2010). New insights into the origin of two new epiphytic Impatiens species (Balsaminaceae) from West Central Africa based on molecular phylogenetic analyses. Taxon 59: 1508-1518.

KHAN, S. A. (2007). New delimitations and phylogenetic relationships of Sabiceeae (Ixoroideae, Rubiaceae) and revision of the Neotropical species of Sabicea Aubl. PhD Thesis, University of Bayreuth. 
Khan, S. A., S. G. Razafimandimbison, B. Bremer \& S. LiedeSchumann (2008). Sabiceeae and Virectarieae (Rubiaceae, Ixoroideae): one or two tribes? New tribal and generic circumscriptions of Sabiceeae and biogeography of Sabicea s.1. Taxon 57: 1-17.

Lachenaud, O. (2009). La flore des plantes vasculaires de la République du Congo: nouvelles données. Syst. Geogr. Pl. 79: 199-214.

Lachenaud, O., T. Stévart, D. Ikabanga, E. C. Ngagnia Ndjabounda \& G. Walters (2013). Les forêts littorales de la région de Libreville (Gabon) et leur importance pour la conservation: description d'un nouveau Psychotria (Rubiaceae) endémique. Pl. Ecol. Evol. 146: 68-74.

Lye, K. A. (2014) Studies in African Cyperaceae 36. Mapania pallescens sp. nov. from Gabon. Nord. J. Bot. 32: 137-138.

Ntore, S., O. Lachenaud, S. Janssens \& S. Dessein (2010). Four new Pauridiantha species (Rubiaceae) reflect the richness of Gabon's rainforests. Belg. J. Bot. 142: 177-193.

Sosef, M. S. M., J. J. Wieringa, C. C. H. Jongkind, G. Achoundong, Y. Azizet Issembé, D. Bedigian, R. G. van den Berg, F. J. Breteler, M. Cheek, J. Degreef, R. B. Faden, P. Goldblatt, L. J. G. van der Maesen, L. Ngok Banak, R. Niangadouma, T. Nzabi, B. Nziengui, Z. S. Rogers, T. Stévart, J. L. C. H. van Valkenburg, G. Walters \& J. J. F. E. DE WILDE (2006). Check-list des plantes vasculaires du Gabon. Checklist of Gabonese vascular plants. Scripta Bot. Belg. 35.

Sosef, M. S. M., D. J. Harris \& K. Armstrong (2007). Novitates Gabonenses 64. A new species of Campylospermum (Ochnaceae) from coastal Gabon. Blumea 52: 15-19.

Verdcourt, B. \& D. M. Bridson (1988). Rubiaceae, part 2. In: Polhill, R. M. (ed.), Fl. Trop. E. Africa.

Walters, G., G. Dauby, T. Stévart, S. Dessein, R. Niangadouma \& O. Lachenaud (2011). Novitates Gabonenses 80: additions and corrections to the flora of Gabon. Edinburgh J. Bot. 68: 423-442.

Wernham, H. F. (1914). A monograph of the genus Sabicea. London, British Museum [Natural History].

Zemagho, L., O. Lachenaud, S. Dessein, S. Liede-Schumann \& B. Sonké (2014). Two new Sabicea (Rubiaceae) species from West Central Africa: Sabicea bullata and Sabicea urniformis. Phytotaxa 173: 285-292.

Zemagho, L., S. Liede-Schumann, B. Sonké, S. Janssens, O. Lachenaud, B. Verstraete \& S. Dessein (in press). The phylogeny of the tribe Sabiceeae (Ixoroideeae-Rubiaceae) revisited, with the proposition of a new subgeneric classification for Sabicea. Bot. J. Linn. Soc. 